\title{
BIRTH ORDER OF MEDICAL STUDENTS AND THE OCCUPATIONAL AMBITIONS OF THEIR PARENTS
}

\author{
PHILLIP SHAVER JOHN R.P. FRENCH, Jr SIDNEY COBB \\ University of Michigan, Ann Arbor, USA
}

\begin{abstract}
Une étude antérieure, faite aux Etats-Unis, a montré que les étudiants en médecine sont en général les aînés de leur famille; cette tendance est spécialement marquée lorsque le père souffre d'un certain déséquilibre dans son statut professionnel, en ce sens que celui-ci est inférieur à ce à quoi il pouvait aspirer de par sa formation. Cette étude a été refaite et étendue en Suède; les conclusions sont les suivantes : (r) Les étudiants en médecine, filles et garçons sont en général les aînés de leur famille. (2) Cette tendance est plus marquée chez les filles dont le père a un statut déséquilibré. (3) Pour les étudiants des deux sexes, la proportion d'ainés est spécialement forte chez ceux qui relatent que leur père a été frustré dans ses aspirations professionnelles. On pourrait donc penser que le fils aîné prend son père comme modèle de rôle professionnel quand le père est satisfait de son travail, tandis que, lorsque le père est frustré, le fils prend pour modèle le rôle que le père n’a pas réussi à atteindre. (4) Conformément aux prédictions basées sur la primogéniture, les effets du rang de naissance, pour les sujets masculins, sont plus marqués dans les zones rurales que dans les villes, mais cette différence ne joue pas pour les filles. Plusieurs problèmes méthodologiques afférant aux recherches sur le rang de naissance sont discutés ici.
\end{abstract}

This paper reports a cross-cultural replication and extension, conducted in Sweden, of a study by Cobb and French (1966) on the connections between parental job aspirations, birth order, and motivation of children to become doctors. It is an attempt to specify some of the intervening processes accounting for the over-representation of first-borns in high achievement groups, including medical students (Coker et al., 1959). Recent reviews of the literature on birth order and social behavior (Sampson, I965; Warren, 1966; Clausen, 1966; Altus, 1967 ) support the long-standing contention (Galton, 1874 ; Schachter, 1963) that first-borns are over-represented among the eminent, especially if " eminence" refers to academic achievement. However, these same reviews contain very little in the way of explanation because few explanations have been consistently supported in past studies. The typical design relates birth order to an outcome variable (e.g., grades, acceptance to graduate or professional school, achievement in science) without presenting data on intervening processes.

What explanations have been offered follow from three distinct frames of reference, as discussed by Bayer (1967) : (I) the pbysiological, attributing differences to intrauterine and perinatal influences; (2) the economic, attributing differences to a family's ability to pay for the first-born's education; (3) the socialpsycbological, attributing differences to variations in socialization practices for children of different birth orders. Although there is reason to believe that such 
physiological and perinatal factors as intrauterine environment, length of labor, and use of forceps in delivery are related to birth order (Weller, 1965), no systematic research has yet demonstrated that these factors can explain differences in academic achievement. They do seem to be important in accounting for physiological correlates of birth order. For example, Udjus (1964) reported data showing that mean height decreases with increasing birth order. Some authors attribute greater vitality or physiological "efficiency" to younger mothers (Douglas and Blomfield, 1958) and use this as an explanation of such physiological correlates. In dealing with a variable like academic achievement, however, it is much more difficult to rule out nonphysiological factors related to mother's age, such as changes in child-rearing practices.

The economic frame of reference seems more likely to be relevant, and its reasoning is attractively simple : " ... families who send their early-born children to receive higher education have spent so much on education that they cannot afford to send their later-born, especially if they have many children or are of low economic means" (Bayer, 1967, p. 550). However, in a study of over 8,000 Americans who received the Ph.D. degree recently, Bayer found no support for hypotheses derived from this explanation. Furthermore, Nichols (1964; cited in Altus, 1967) in a study of National Merit Scholarship finalists, found that among very high scorers there was a remarkable over-representation of first-borns. Thus, it seems that the relationship between academic achievement and birth order exists even at the pre-college level, where the economic argument carries less weight. Several social-psychological explanations have been attempted. After considering them together, Altus ( 1967 ) concluded that "... the most prominent of the presumed social "causes" is likely to be the differential parental treatment accorded children of different ordinal positions, to greater " conscience" development, greater dependence on adult norms, and higher expectations of achievement falling to the lot of the first-born" (Altus, 1967, p. 31 ). According to this view, the observed intellectual superiority is due to experience rather than genetics or physiology. Hunt's (196I) review of the literature on the development of intelligence suggests that this is possible. It also seems likely that much of the relationship is due to differences in motivation; relationships between birth order and tested intelligence are small in comparison with the "marked over-representation of the first-born in studies based on achievement" (Barry, I967, p. 442).

A recent study by Cobb and French (1966) lends support to the "expectation of achievement "hypothesis by demonstrating that the oldest to youngest ratio (expected to be one by chance) is especially high, 19/1, among male medical students whose fathers were high in education and relatively low in job status. In interpreting these effects of status incongruence the authors assumed that fathers with a high level of education aspire to high status occupations; if they fail to achieve them they suffer from feelings of frustration and failure. It was further assumed that such fathers tend to project their frustrated occupational ambitions more onto their first-born sons than onto later-born, either because of stronger influences directed toward the oldest or because of the greater susceptibility of the oldest to social infuence (Sampson, 1965). As Blau and Duncan (1967) suggest, it is also most likely that a man will be status incrongruent at the time of his first child's birth, when he is just beginning his career. This process 
of occupational choice should apply especially to medicine because it is a high status profession requiring many years of education, and yet it is well known to all children at an early age. This process may not apply, however, to all occupations and to all types of students. For the present attempt to replicate and extend the findings of Cobb and French in another country, Sweden was chosen for two reasons. First, the proportion of females in medical school is much higher there; Cobb and French could draw no conclusions about American female medical students because there were so few in their sample. Second, there has been some speculation about the effects of primogeniture on the birth orderachievement relationship, but apparently no one has investigated it. On the one hand, in a society which guarantees inheritance of the family farm to the oldest son, we might expect relatively few first-born males to apply to medical school. On the other hand, if achievement expectations are higher for rural first-born males and more attention is paid them, we might expect an unusually great over-representation of oldest males among Swedish medical students from

rural areas. Part of the answer would be provided by statistics showing what proportion of oldest sons generally choose to stay on family farms in Sweden. Sweetser (1964) reports that in neighboring Finland the proportion has been steadily decreasing. Following Cobb and French we favored the latter hypothesis.

Our predictions were as follows :

I. Since admission to medical school requires both academic excellence and high motivation, there should be an over-representation of first-borns in medical school among males and females. 2. Among students whose fathers are high in education but relatively low in job status the birth order effect should be especially strong, offering further support for the "projection of frustrated ambitions onto the first-born. "This relationship should be stronger for males than for females, assuming that males are more likely to receive influence from the father. 3. A more direct measure of frustrated parental job ambitions, as recalled by the child, should yield results consistent with the hypothesis about projection of frustrated ambitions. That is, among medical students whose fathers and/or mothers aspired to an occupation they never attained the overrepresentation of first-borns should be great. The effect should be especially strong in cases where the parent aspired to a medical career but failed to achieve it. 4. Because in rural Sweden primogeniture is still salient, we would expect the over-representation of oldest males to be greater for students with rutal as opposed to urban backgrounds. This relationship should be less strong for females, to whom primogeniture applies less strongly or not at all.

\section{MET'HOD}

The subjects of this study were all medical students in Gothenburg, Sweden. One hundred and eighty-three males and 1 i 2 females, approximatively $50 \%$ of those contacted, completed a three- page questionnaire mailed to them by a fellow student in the winter of 1967 . It contained questions concerning the parents' ages, occupations, incomes, educational histories, and marital status - the purpose being to control on these variables in the analyses presented below. Also, the relevant family structure information was requested, number of brothers and sisters and the ordinal positions of all children. There were several questions designed to assess the subject's motivation to attend medical school : when he first wanted to go, what steps in the Swedish 
school system he took or would have been willing to take to reach medical school, and how much each parent encouraged him to attend. Finally, there were questions asking the subject to recall whether his father (mother) ever aspired to an occupation he (she) did not attain, and, if so, what it was.

Most of our results are in the form of oldest to youngest ratios for various subgroups of the sample studied. In a randomly selected sample from a national population, this ratio would be close to one, since in every family with two or more children there is one oldest and one youngest child. Of course, in a cohort of almost identical age, such as the one studied, there may be a slight deviation from this ratio of one, due to secular trends in the marriage rate or mean family size or both. Inspection of these statistics for the appropriate years suggests that for all of Sweden the effect was not large; and, within our sample, an analysis of variance indicated that the mean ages of first-born, intermediate, and last-born students were not significantly different. Because the oldest to youngest ratio is expected to be one only for families with two or more children, no only children are included in the analysis.

\section{RESULTS}

Tables I and 2 show, for males and females respectively, the results bearing on our hypothesis that first-borns would be over-represented among Swedish medical students. In these tables observed and expected frequency distributions are compared for oldest, intermediate, and youngest children arranged according to sibship size (number of children in the family). Both distributions are highly

TABLE 1

EXPECTED AND OBSERVED DISTRIBUTIONS OF MALES

\begin{tabular}{|c|c|c|c|c|c|c|c|c|}
\hline \multirow{3}{*}{$\begin{array}{c}\text { Sibship } \\
\text { size }\end{array}$} & \multicolumn{6}{|c|}{ Position in sibship 1} & \multirow{3}{*}{ Total } & \multirow{3}{*}{$\mathrm{O} / \mathrm{Y}$} \\
\hline & \multicolumn{2}{|c|}{ Oldest } & \multicolumn{2}{|c|}{ Intermediate } & \multicolumn{2}{|c|}{ Youngest } & & \\
\hline & Obs. & Exp. & Obs & Exp. & Obs & Exp. & & \\
\hline 2 & 39 & 30 & o & 0 & $2 \mathrm{I}$ & 30 & 60 & $39 / 21$ \\
\hline 3 & 28 & 20 & 19 & 20 & 13 & 20 & 60 & $28 / 13$ \\
\hline $4+$ & II & 9.33 & 24 & 21.33 & 5 & 9.33 & 40 & $\mathrm{II} / 5$ \\
\hline Total & $7^{8}$ & 59.33 & 43 & 41.33 & 39 & 59.33 & 160 & $78 / 39$ \\
\hline
\end{tabular}

1 This table excludes 23 only children.

unlikely; $\chi^{2}$ computed for the total distribution in each table were highly significant (for males, $\chi^{2}=12.91, p<.005$; for females, $\chi^{2}=16.5 \mathrm{I}, p<.001$ ). The oldest to youngest ratio for males is 2.00 ; for females it is 2.24.

These ratios are comparable to the $\mathbf{2 . 4 3}$ obtained for American male medical students by Cobb and French, although we were surprised to find that the ratio for Swedish males tended to be lower than the ratios for American males and Swedish females. The effect of the primogeniture tradition was expected to raise the ratio for Swedish males higher than that of American males. Perhaps some of the first-born sons stayed on family farms (see data presented below for rural-urban comparisons). The high female ratio may reflect the extra motivation and ability required for a girl to enter a difficult profession. One other 
unexpected result should be noted. Cobb and French found that the oldest to youngest ratio increased with increasing sibship size : I.S for sibship size 2;

TABLE 2

EXPECTED AND OBSERVED DISTRIBUTIONS OF FEMALES

\begin{tabular}{|c|c|c|c|c|c|c|c|c|}
\hline \multirow{3}{*}{$\begin{array}{l}\text { Sibship } \\
\text { size }\end{array}$} & \multicolumn{6}{|c|}{ Position in sibship 1} & \multirow{3}{*}{ Total } & \multirow{3}{*}{$\mathrm{O} / \mathrm{Y}$} \\
\hline & \multirow{2}{*}{\multicolumn{2}{|c|}{\begin{tabular}{c}
\multicolumn{2}{c}{ Oldest } \\
Obs. Exp.
\end{tabular}}} & \multicolumn{2}{|c|}{ Intermediate } & \multicolumn{2}{|c|}{ Youngest } & & \\
\hline & & & Obs. & Exp. & Obs. & Exp. & & \\
\hline 2 & 25 & I7 & o & 0 & 9 & 17 & 34 & $25 / 9$ \\
\hline 3 & 18 & Io & 8 & Io & 4 & IO & 30 & I $8 / 4$ \\
\hline $4+$ & 13 & 9.33 & I 4 & 20.33 & 12 & 9.33 & 39 & I $3 / 12$ \\
\hline Total & 56 & 36.33 & 22 & 30.33 & 25 & 36.33 & 103 & $56 / 25$ \\
\hline
\end{tabular}

1 This table excludes 9 only children.

3.I for 3 ; and 10.5 for $4+$. They assumed that this reflected the decreasing strength of the father's projected occupational aspirations for later-born males. A similar but nonsignificant trend is observed for Swedish males : 1.86 for sibship size 2; 2.I 5 for 3 ; and 2.20 for $4+$. For the females, however, the highest ratio occurs for families with three children (4.50), while the ratio for sibship of four or more is little more than one ( 1.08 ).

Tables 3 and 4 present results bearing on our second and third hypotheses. The underlying assumption is that fathers with frustrated occupational ambitions project these onto their first-born child, especially if the child is a male. Cobb and French tested this thesis indirectly by assuming that fathers who are relatively high in education but low in occupational status will have frustrated ambitions. Their study yielded an extremely high oldest to youngest ratio ( $19 / 1$ ) among males whose fathers were "status incongruent" in this sense.

Table 3 represents an attempt to replicate the classification used by Cobb and Franch. The three heavy-typed cells in the upper righthand corner of each half of the table are of interest because these contain ratios for students who have status incongruent fathers. For males the hypothesis is not supported; the oldest to youngest ratio is less than one. For females the results are as expected. In the three cells of interest the total ratio is 5.00 , compared to 2.37 for the remainder of the table $(p<.05)$. However, Table 3 presents a weak test of the hypothesis because no cases fell in the strongly incongruent cell. These results must be considered in conjunction with Table 4. Here the question about frustrated occupational ambitions was asked directly. The results are reported in three categories : (I) father attained the occupation to which he aspired; (2) father aspired to a non-medical job which he failed to attain; (3) father aspired to a medical or paramedical job (e.g., veterinarian) which he failed to attain. As stated in our third hypothesis, we expected the oldest to youngest ratio to be larger in the third category, because frustrated ambitions are assumed to be projected onto the first-born child. Whete these ambitions were specifically oriented 
toward the medical profession the effect was expected to be greatest. The results support this interpretation. For both males and females the ratio shows a signif-

TABLE 3

OLDEST TO YOUNGEST RATIOS FOR CATEGORIES OF FATHER'S OCCUPATION AND EDUCATIONAL LEVEL ${ }^{1}$

\begin{tabular}{|c|c|c|c|c|c|}
\hline & & \multicolumn{4}{|c|}{ Fathers' occupation } \\
\hline \multicolumn{2}{|c|}{ Father's education } & $\begin{array}{c}\text { Owners, managers, } \\
\text { professionals }\end{array}$ & $\begin{array}{c}\text { Teachers, technical, } \\
\text { sales }\end{array}$ & $\begin{array}{l}\text { Laborers } \\
\text { and farmers }\end{array}$ & 'Total \\
\hline \multirow[t]{2}{*}{ Males } & $\begin{array}{l}\text { University } \\
\text { Secondary } \\
\text { Grade }\end{array}$ & $\begin{array}{r}20 / 7 \\
16 / 8 \\
1 / 1\end{array}$ & $\begin{array}{r}3 / 7 \\
18 / 6 \\
8 / 2\end{array}$ & $\begin{array}{l}0 / 0 \\
2 / 0 \\
9 / 6\end{array}$ & $\begin{array}{l}23 / 14 \\
36 / 14 \\
18 / 9\end{array}$ \\
\hline & Total & $37 / 16$ & $29 / 15$ & $\mathrm{I} I / 6$ & $77 / 37$ \\
\hline \multirow[t]{2}{*}{ Females } & $\begin{array}{l}\text { University } \\
\text { Secondary } \\
\text { Grade }\end{array}$ & $\begin{array}{r}8 / 8 \\
\mathrm{I} 2 / 1 \\
1 / 0\end{array}$ & $\begin{array}{r}8 / x \\
16 / 3 \\
4 / 4\end{array}$ & $\begin{array}{l}0 / 0 \\
2 / 1 \\
4 / 3\end{array}$ & $\begin{array}{r}16 / 9 \\
30 / 5 \\
9 / 7\end{array}$ \\
\hline & Total & $2 I / 9$ & $28 / 8$ & $6 / 4$ & $55 / 21$ \\
\hline
\end{tabular}

1 Heavy-typed cells indicate telatively high education level with telatively low job status.

icant monotonic increase $(p<.05)$ in the predicted direction. Notice in particular that all students are first-born who reported having a father with frustrated ambitions to become a medical professional.

TABLE 4

OLDEST TO YOUNGEST RATIOS FOR CATEGORIES OP FATHER'S AND MOTHER'S JOB ASPIRATIONS

\begin{tabular}{l|cc}
\hline \hline & Males & Females \\
\cline { 2 - 2 } & & \\
Father's job aspirations & $52 / 32$ & $33 / 16$ \\
Attained & $14 / 4$ & $18 / 3$ \\
Unattained (nonmedical) & $5 / 0$ & $4 / 0$ \\
Unattained (medical or paramedical) & & \\
& & \\
& & \\
Mother's job aspirations & $52 / 26$ & $26 / 14$ \\
Attained & $16 / 7$ & $19 / 5$ \\
Unattained (nonmedical) & $5 / 4$ & $9 / 4$ \\
Unattained (medical or paramedical) & & \\
&
\end{tabular}

In light of these results we question the validity of the coding scheme for Swedish occupations used in Table 3. The hypothesis which we intended to test by identifying status incongruence is supported by direct questioning, but 
is not supported (for males) for the status incongruence analysis. We attempted to replicate as closely as possible the coding system used for Americans by Cobb and French. Because we lacked detailed information about some of the jobs named, however, we often had to rely on annual income as an index of status. Recently other research has shown that income is not a good substitute for status or prestige ratings in analyses of status incongruence (Stanislav Kasl, personal communication). Further research on this question would require more precise descriptions of father's occupation and a status classification system designed especially for Sweden. The lower portion of Table 4 shows oldest to youngest ratios for the three categories of mother's job aspirations. For males, mother's aspirations apparently have little effect; this is probably due to the greater importance of the father as a role model for males and as the parent for whom occupation is most salient. For females there is a nonsignificant trend in the predicted direction : this suggests that the girls, compared to the boys, pay more attention to their mother's achievement expectations, as would be expected on the assumption that the mother is important as a role model for females. Note, however, that the ratio is less for unattained medical aspirations than for unattained nonmedical aspirations. Investigation of the responses involved indicated that most of the paramedical aspirations were directed toward nuring. Perhaps this does not have as strong an effect as ambitions to become a doctor.

Table $s$ presents oldest to youngest ratios for various categories of childhood residence. We anticipated that the ratio for males raised in rural areas would be

TABLE 5

OLDEST 'TO YOUNGEST RATIOS FOR CATEGORIES OF CHILDHOOD RESIDENCE

\begin{tabular}{c|c|cccc|c}
\hline & City & \multicolumn{5}{|c}{ Non-city } \\
\cline { 2 - 7 } & Total & Farm & $\begin{array}{c}\text { Moved from } \\
\text { farm to city }\end{array}$ & $\begin{array}{c}\text { Moved from } \\
\text { city to farm }\end{array}$ & Village & Totai \\
\hline Males & $50 / 3 \mathrm{I}$ & $5 / 2$ & $3 / 0$ & $4 / 0$ & $13 / 3$ & $25 / 5$ \\
\hline Females & $42 / 13$ & $3 / 5$ & $0 / 2$ & $0 / 0$ & $11 / 2$ & $14 / 9$ \\
\hline
\end{tabular}

higher than for males raised in cities (where the emphasis on primogeniture has declined fastest). The results for males in Table s support our fourth hypothesis, although the number of cases in the farm category is small. If all categories except " city" are combined, on the grounds that some farm or village background is more likely than an urban background to be associated with the tradition of primogeniture, the hypothesis is definitely supported. The ratio for "city" males is 50/3r; for "non-city" males it is $25 / 5\left(\chi^{2}=4.66, p<.05\right)$. This procedure yields different results for females. The ratio of $3 / 5$ in the farm category is based on too few cases, but it is lower than the $42 / 13$ for "city" - consistent with our hypothesis, although we did not predict the especially high ratio for urban females. Notice that for the village category the ratio is II $/ 2$, as high as for males. This suggests that including these villagers in the same 
category with students from farms may be misleading. The question which yielded these results allowed five possible answers; a check could be placed by "city", "farm", " moved from farm of city", " moved from city to farm", or "other (please specify)". All the cases reported in Table 5 as "village" were actually checked as "other" on the questionnaire, and "village" was specified by the respondent. The resulting high oldest to youngest ratio for the category may therefore be due either to an over-representation of first-borns among students from villages or to the greater willingness of first-borns to go out of their way to differentiate between "city" (which required only a check) and "village" (which required written specification). The latter explanation is consistent with findings indicating that first-borns are more anxious to please others (Dittes, 1961; Sampson, 1965) and more compulsive (Kayton and Borge, I967).

One further analysis involving place of childhood residence is reported in Table 6. Primogeniture applies to the first-born male in a family, and it is therefore possible that its effect would be observable in the male regardless of whether

TABLE 6

COMPARISON OF SONSHIP DISTRIBUTIONS FOR CITY AND NON-CITY MALES

\begin{tabular}{|c|c|c|c|c|c|c|}
\hline & \multirow{2}{*}{$\begin{array}{l}\text { Sonship } \\
\text { size }\end{array}$} & \multicolumn{5}{|c|}{ Position in sonship 1} \\
\hline & & Oldest & Intermediate & Youngest & Total & $\mathrm{O} / \mathrm{Y}$ \\
\hline \multirow[t]{2}{*}{ City } & $\begin{array}{l}2 \\
3 \\
4+\end{array}$ & $\begin{array}{r}33 \\
9 \\
0\end{array}$ & $\begin{array}{r}0 \\
12 \\
1\end{array}$ & $\begin{array}{r}17 \\
5 \\
0\end{array}$ & $\begin{array}{r}50 \\
26 \\
I\end{array}$ & $\begin{array}{c}33 / 17 \\
9 / 5 \\
0 / 0\end{array}$ \\
\hline & Total & 42 & 13 & 22 & 77 & $42 / 22$ \\
\hline \multirow[t]{2}{*}{ Non-city } & $\begin{array}{l}2 \\
3 \\
4+\end{array}$ & $\begin{array}{r}13 \\
6 \\
2\end{array}$ & $\begin{array}{l}0 \\
2 \\
1\end{array}$ & $\begin{array}{l}4 \\
\text { I } \\
\text { I }\end{array}$ & $\begin{array}{r}17 \\
9 \\
4\end{array}$ & $\begin{array}{r}13 / 4 \\
6 / 1 \\
2 / 1\end{array}$ \\
\hline & Total & $2 \mathbf{I}$ & 3 & 6 & 30 & $21 / 6$ \\
\hline
\end{tabular}

1 This table excludes 50 only sons in the city category and is in the non-city category.

they had older sisters. In Table 6 observed and expected distributions of position in the sonship (male children) are compared. They are separated into two categories, "city" and "non-city". For "city," the oldest to youngest ratio is $42 / 22$; for "non-city" it is $21 / 6$. The difference is in the expected direction but is not statistically significant. It is not quite as large as the difference reported for males in Table 5, although the total ratio of $6_{3} / 28$ is higher than in Table $\mathrm{r}$. A similar analysis for females yielded an oldest to youngest ratio of I.30 for " city" and ${ }^{2} .6_{3}$ for " non-city". These are almost identical, and both are less than the ratio of $\mathbf{2 . 2 4}$ in Table $\mathbf{2}$. In general, then, the results suggest that among male medical students the oldest to youngest ratio is higher for those with rural backgrounds, and this is consistent with the assumption that primogeniture is 
more salient there. This conclusion must be tentative because of the small number of cases in the farm category and the possible confounding of background with willingness to do extra work in filling out a questionnaire. The results for females were not completely as anticipated; the ratio was unexpectedly high for girls raised in cities. Perhaps this is due to differences between rural and urban environments in the opportunity structure for girls with high aspirations.

One question was raised by our analysis which was not included among the hypotheses : What is the relationship between the parents' actual occupations and the oldest to youngest ratio? Some children may choose the same occupations as their parents, especially if the parents are satisfied. We were particularly interested in the oldest to youngest ratio for males among those whose fathers were in medicine. Only one relationship was notable : the ratio was higher for males whose fathers are in medicine than for males whose fathers have nonmedical jobs. This suggests that first-born males take their father as an occupational role model when he is happy with his position; the earlier results indicate that they take the father's desired but unattained role as a model when he is not happy with his position.

\section{DISCUSSION}

Several methodological problems have occurred in past attempts to clarify the relationship between birth order and occupational or academic achievement. Previous researchers, for example, have often ignored sex differences, sex composition of the sibship, and socio-economic status. We attempted to consider these variables, but a number of important methodological and theoretical problems remained.

I. Many earlier studies have used volunteers such as patients in clinics and hospitals or subjects in an experiment, usually college students. It is now believed that volunteering is related to birth order (Capra and Dittes, 1962; Suedfeld, I 964 ). This is also a problem in our study because only $50 \%$ of the sample returned questionnaires. It is possible that more first-borns than last-borns chose to comply with our request, and this might account for part of the high oldest to youngest ratio that we found. However, it is unlikely that it could account for the relationship between birth order and occupational frustration of the father.

2. Many previous samples have been too small for adequate analysis -..- often containing less than fifty persons. Although we included 300, it was still impossible to control simultaneously on several variables. It would be worthwhile for future studies to include many more.

3. There is always a possibility that the over-representation of first-borns among high academic achievers is related to the mother's age at the time her child is born. Table 7 indicates that, as one would expect, for both males and females the mothers of later-born children are older. Since we did not have a large enough sample to control on mother's age, it is possible that this variable has some effect. For example, related physiological variables may be important; or there may be differences in child-rearing practices between older and younger mothers.

4. There is also the problem of parental deprivation through death or divorce, which is expected to decrease the size of the sibship and thus increase the pro- 
portion of first-borns. However, when only children are excluded in our analyses, the oldest to youngest ratio remains unaffected by this artifact. Thus, any effects of parental deprivation must operate via changes in family structure. The oldest

TABLE 7

MOTHER'S AGE AT BIRTH OF RESPONDENT

\begin{tabular}{|c|c|c|}
\hline Sex & Position in sibship & Mean age of mother \\
\hline Males & $\begin{array}{l}\text { Only children } \\
\text { Firstborns } \\
\text { Intermediates } \\
\text { Lastborns }\end{array}$ & $\begin{array}{l}30.65(\mathrm{~N}=23) \\
27.23(\mathrm{~N}=78) \\
29.9^{8}(\mathrm{~N}=43) \\
34.00(\mathrm{~N}=39)\end{array}$ \\
\hline Females & $\begin{array}{l}\text { Only children } \\
\text { Firstborns } \\
\text { Intermediates } \\
\text { Lastborns }\end{array}$ & $\begin{array}{l}30.33(\mathrm{~N}=9) \\
28.45(\mathrm{~N}=56) \\
31.59(\mathrm{~N}=22) \\
35.88(\mathrm{~N}=25)\end{array}$ \\
\hline
\end{tabular}

to youngest ratio for males who reported one or both parents absent was $10 / 16$; for females it was $7 /$ ro. Both are obviously low compared to the overall ratios for each group. This suggests either that first-borns are responsible for their families in cases of parental loss and thus are not likely to make it into medical school, or that decreased parental influence is responsible for lower aspirations in first-borns. We did not have enough cases to study these people separately. However, if they are removed from the sample, the oldest to youngest ratios are, of course, increased : for males it rises from 2.00 to $2.9^{6}$ and for females from 2.24 to 3.27 .

5. Finally, we were only able to begin to detect intervening processes that would account for increased academic achievement of first-borns. A great improvement would be made by interviewing parents directly and by studying first-borns as children in interaction with their parents. A recent excellent study by Hilton (1967) has provided an example.

Most of these methodological problems arise when assessing the over-representation of first-borns in high academic achievement groups. They are, therefore, relevant to the results reported in Tables I and 2. However, they do not apply in any obvious way to within-group comparisons and hence do not discount the main finding of this study, that first-borns are especially numerous among high achievers who believe that their parents had frustrated occupational ambitions. It remains for future studies including other professional groups and other societies, and which deal with the methodological issues we have raised, to further explicate the relationship between birth order and academic achievement.

\section{REFERENCES}

Altus, W.D. Birth order and its sequelae. International Journal of Psycbiatry, 1967, 3, 23-32.

BARry, H., Jr. A century of wasted opportunity. International Journal of Psychiatry, I967, 3, $32-36$. 
BAYER, A.E. Birth order and attainment of the doctorate. A test of economic hypotheses. American Journal of Sociology, 1967, 72, 540.550.

Blau, P.M. \& Duncan, O.D. The American octupational structure. New York, N.Y. : Wiley, 1967.

CAPRA, P.C. \& Dittes, J.E. Birth order as a selective factor among volunteer subjects. Journal of Abnormal and Social Psycbology, 1962, 64, 302 .

Clausen, J.A. Family structure, socialization and personality. In L. \& M. Hoffman (Eds), Reviem of child development research. Vol. 2. New York, N.Y. : Russell Sage Foundation, 1966.

Совв, S. \& French, J.P.R., Jr. Birth order among medical students. Jokrnal of the American Medical Association, 1966, 195, 172-173.

Coker, R.E., Back, K.W., Donnelly, T.G., Miller, N. \& Phillips, B.S. Public health as viewed by the medical student. American Journal of Public Health, 1959, 49, 601-609.

Drrtes, I.E. Birth order and vulnerability to differences in acceptance. American Psycbologist, I961, 16, 358. (Abstract)

Douglas, J.W.B. \& Blomficld, J.M. Children under five. London : Allen and Unwin, 1958.

Galton, F. Englisb men of science. Their nature and nurture. London : Macmillan, 1874.

HiLton, I. Differences in the behavior of mothers toward first- and later-born children. Journal of Personality and Social Psucbology, 1967, 7, 282-29o.

HunT, J.M. Intelligence and experience. New York, N.Y. : Ronald, $196 \mathrm{I}$.

KAYTON, L. \& BORGE, G.F. Birth order and the obsessive-compulsive chatacter. Archives of General Psycbiatry, 1967, 17, $751-754$.

NichoLs, R.C. Birth order and intelligence. Unpublished manuscript, National Merit Scholarship Corporation, 1964 .

SAMpson, E.E. The study of ordinal position. Antecedents and outcomes. In B. Maher (Ed.), Progress in experimental per sonality research. Vol, 2. New York, N.Y. : Academic Press, 1965.

Schachter, S. Birth order, eminence, and higher education. American Sociological Review, I963, $28,757-768$.

SUEDRELD, P. Birth order of volunteers for sensory deprivation. Journal of Abnormal and Social

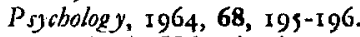

SweEtSER, D.A. Urbanization and the patrilineal transmission of farms in Finland. Acta Sociologica, 1964, 7, $215-224$.

Udjus, L.G. Anthropometrical changes in Norwegian men in the twentieth century. Oslo : University of Oslo Press, 1964.

Warren, J.R. Birth order and social behavior. Psycbological Bulletin, I966, 6s, 38-49.

WhLler, G.M. Arousal effects on the newborn infant of being first- or later-born. American Journal of Orthotsycbiatry, 1965, 35, 341-342. (Abstract) 